\title{
粒子充てん層による清澄ろ過に関する研究
}

狮 村 雄 二*

Yuji YOSHIMURA

\section{1. 研究を始めた動機}

粒子充てん層による清澄ろ過法は用排水処理等におい て広く実施されているが，処理対象となる原液の特性が 千差万別であるために，個々のろ過操作に打けるろ過効 率の推定は実験および経験的なデータによらざるを得な いのが現状である。

そこで本研究では，ェアロゾルろ過に対して従来から 吉岡研究室 (京都大学化学工学科)で用いられてきた粒 子軌跡の解析によるら過効率の推算法を, 液相の場合に も適用することが可能かどらか，また可能とするために は液相に特有などのよらな作用力を考慮しなければなら ないか等を検討することを主目的とした。

\section{2. 主な成果}

本研究で得られた成果の主なものを以下に示す。

1）粒子軌跡の解析による捕集効率の推定法が液相の

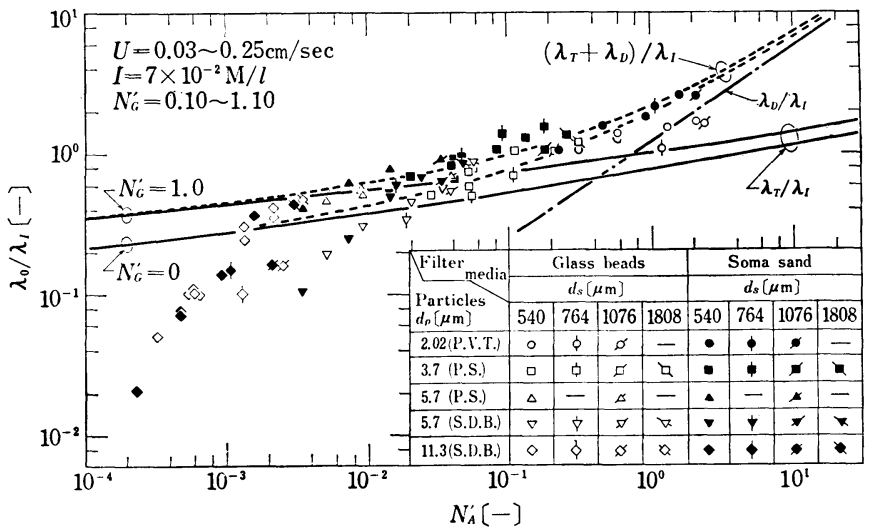

Fig. 1 Comparison of experimental values with theoretical ones under conditions where double-layer repultion forces between suspended particles and filter media were negligible ; $\lambda_{I}$ : intial filter coefficient due to interception, $I$ : ionic strength, $d_{s}$ : grain diameter (geometric mean of sieve openings)

昭和 57 年 1 月 12 日受付

* 化学技術研究所工業触媒部 ( 305 茨城県筑波郡谷田部町東 1-1)

TE L 0298-54-4534
場合にも適用可能であることを，球形粒子（標準ラテッ クス粒子）が単一円筒（ガラス瀻維）上に捕捉されてい く状況の観測と理論計算（捕集効率および捕集量分布） の一致により確かめた。

2）ろ材粒子および懸濁粒子が共に球形である場合に ついて，粒子充てん層内の流れを桑原の式で近似し，粒 子に働く流体の抗力, 重力, van der Waals 力等を考 慮して懸濁粒子の軌跡を解析し, 万過効率 $\left(\lambda_{T}\right)$ を推算 した。ただし， $\lambda_{T}=-\ln \left(C_{\text {out }} / C_{\mathrm{ln}}\right) / L ， L$ はろ層厚さ， $C_{\text {in }}$ および $C_{\text {out }}$ はろ層入口および出口における懸濁粒 子濃度である。この結果に抁散の効果 $\left(\lambda_{D}\right)$ を重冨して 求められる過効率 $\left(\lambda_{T}+\lambda_{D}\right)$ を実測值と比較した結果, 粒子一ろ材間の電気二重層反発力が無視でき，捕捉粒子

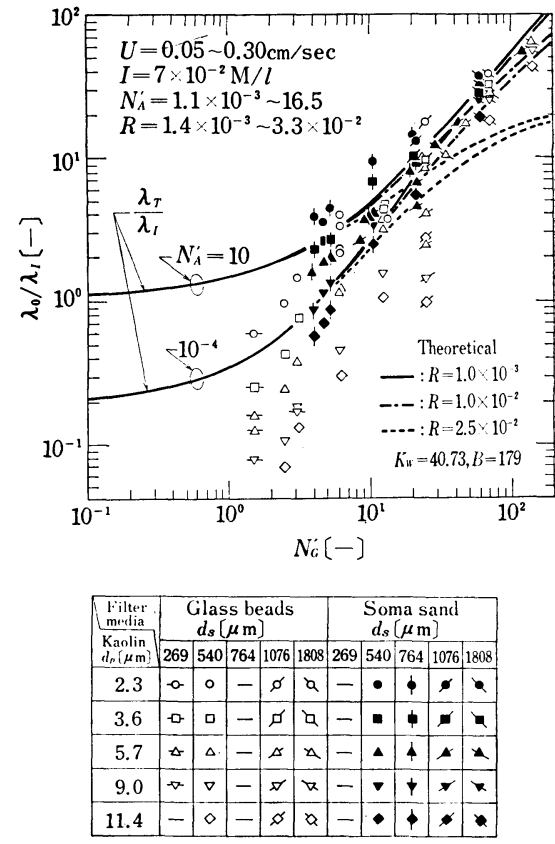

Fig. 2 Comparision of experimental values with theoretical ones under conditions whese double-layer repultion forces between suspended particles and filter media were negligible 


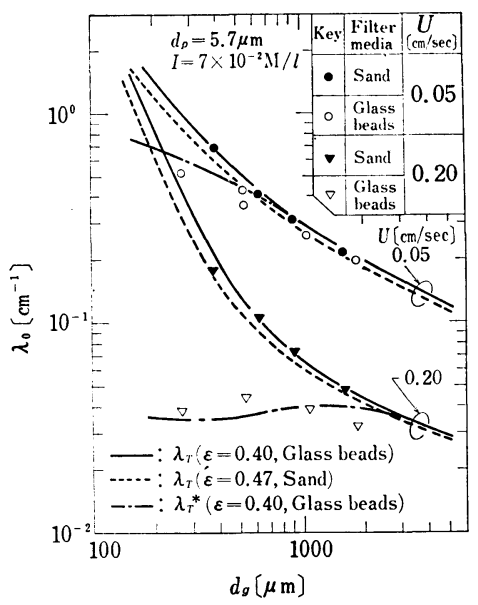

Fig. 3 Comparison of experimental initial filter coefficients with calculated ones by semiempirical expressions

の掃流力による脱離が無い場合, 両者には良好な一致が みられることを確かめた（Fig.1)。

3）ろ材粒子が砂などのよらに非球形である場合には 比表面積径 $\left(d_{g}\right)$ を，懸濁粒子がカオリン粒子のように 非球形である場合にはストークス径，または等体積球相 当径 $\left(d_{p}\right)$ を代表径としてとれば，2）で得た結果が準 用できることを実験的に確かめた（Fig. 2)。

4）万過速度（U）が大となるに従い，万過効率の実 測値は理論値より小さい側に偏倚する傾向がある。これ は，ろ材上に捕捉された粒子に作用する液の掃流力が粒 子一ろ材間に作用する付着力を超える時に起こる脱離現 象によるものと考え，粒子一ろ材間の付着力を遠心法と 剪断流れ法により測定した。この結果より付着効率を算 出し，2)で得られた理論值を補正すれば $\left(\lambda T^{*}\right)$, 上述の 偏倚を説明できることを示した（Fig. 3)。

5）脱離が起こらない条件下の初期ろ過 係数 $\lambda_{0}$ （清 浄万層のろ過性能を表す指標) を5つの無次元量 $\left(N_{A}{ }^{\prime}\right.$, $\left.N_{G}{ }^{\prime}, K_{W}, R, B\right)$ の関数として表す推算式を前述の数 值計算結果より求めた（Fig.4）。ただし， $N_{A}{ }^{\prime}$ は修正 付着力パラメーター ( $\propto$ 吸引力/粘性抗力), $N_{G}{ }^{\prime}$ は修 正重力パラメーター（ $\propto$ 重力／粘性抗力）， $K_{W}$ は桑原 流れパラメーター，Rはさえぎりパラメーター，Bは

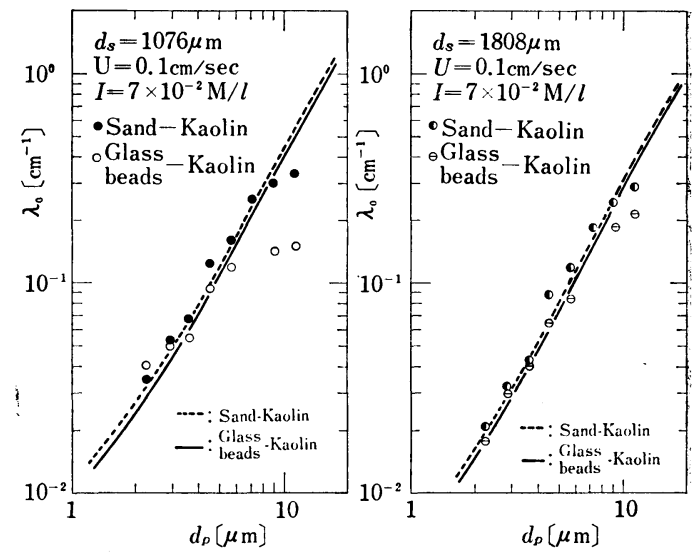

Fig. 4 Comparision of experimental initial filter coefficients with corrected values considering adhesion efficiency; $\varepsilon$ : porosity

van der Waals 力に対する電磁気的遅延パラメーター である。

6）粒子一ろ材間に働く電気二重層反発力が吸引力よ りも支配的となる場合に生じるろ過効率の低下は，2)で 得られた理論值に付着効率の補正を行えば十分に説明で きることを明らかにした。

\section{3. 研究を終えて}

本研究では, 粒子充てん層清澄ろ過器のろ過初期にお ける性能が系の物性值と操作変数から十分に推算できる ことを示した。このことは沪過装置設計の基礎として有 益な知見を与えるものであるが，清澄沪過装置の設計お よび操作を可能にするためには, 粒子捕捉量の增大に伴 ら性能および圧力損失の変化の定量化がさらに必要であ る。したがって, 今後はこの方面でのより一層の精力的 研究が望まれる。また本研究は, その対象がろ過初期に 限定されてはいるものの, 万過現象の理解に非常に有益 な知見を与えると考穴られる。この知見によれば， 万過 現象に関与している界面化学的因子の影響の差異を積極 的に利用した “充てん層による懸濁粒子の選択的分離 (たとえばサスペンジョンクロマトグラフィー)”等の応 用も可能であると考えられる。

（学位受与 昭和56年 3 月 京都大学） 